\title{
MALE AND FEMALE WORKERS. GENDER TREATMENT THROUGH PIXAR'S FILMS
}

TRABAJADORES Y TRABAJADORAS. EL TRATAMIENTO DE GÉNERO A TRAVÉS DE LAS PELÍCULAS DE PIXAR

\author{
Nerea Cuenca-Orellana \\ Universidad de Burgos \\ nerea.cuenca.orellana@gmail.com \\ orcid.org/0000-0003-2888-8403
}

Patricia López-Heredia Universidad Autonoma de Madrid patricia.lopezh01@gmail.com orcid.org/0000-0001-6935-2707 
Abstract: The concept of 'work' encompasses knowledge, representations, activities and social relations that organize and hierarchize society through roles and norms. During more than fifty years, Disney represented women as the angel from the home and men as brave and very hard workers. The distribution of tasks has been progressively modified in our Western society, in animated films as well. In 1989 a new era started in animation films: Disney changed some characteristics in male and female characters, but the representation of female workers did not appear until 2009 with The Princess and the Frog. Tiana is the first worker princess; she is a waitress that wants to run her own restaurant and she gets it at the end of the film. But, in 2009, Pixar had released ten films and its first worker princess was the main character of Bug's life (John Lasseter, 1998). At first sight, this seems as a very high evolution, but this work wants to discover how Pixar has represented the world of work: as a way of dividing characters depending on its gender or as a way of developing and showing equality to the youngest spectators?

Keywords: characters; animation; gender; world of work.

Resumen: Dentro del concepto 'trabajo' se engloban saberes, representaciones, actividades y relaciones sociales que organizan y jerarquizan la sociedad mediante roles y normas. Durante más de cincuenta años, se representó a las mujeres como el ángel del hogar y a los hombres como valientes y trabajadores. El reparto de tareas se ha modificado progresivamente en nuestra sociedad occidental, también en el cine de animación. En 1989 comenzó una nueva era en las películas de animación: Disney cambió algunas características en los personajes masculinos y femeninos, pero la representación de personajes en esferas laborales no apareció hasta 2009 con Tiana y el sapo. Tiana es la primera princesa trabajadora, una camarera que quiere dirigir su propio restaurante y lo consigue al final de la película. Pero, en 2009, Pixar había estrenado diez películas y su primera princesa trabajadora fue la protagonista de Bichos (John Lasseter, 1998). A primera vista, esto parece una gran evolución, pero, en este trabajo se busca descubrir cómo Pixar ha representado el mundo laboral: ¿lo ha hecho como una forma de dividir a los personajes según su género o como una forma de desarrollar y mostrar la igualdad a los espectadores más jóvenes?

Palabras clave: personajes; animación; género; mundo laboral. 


\section{Introduction}

For centuries, it was considered that the differences between masculinity and femininity were determined by nature (Veissière, 2018: 6). However, since the second wave of the feminist movement took place in the United States in the sixties, researchers concluded that the roles each gender carries out are determined by the gender social system (Bogino, 2017: 163). This system, from the beginning of Western civilization, had allotted women the domestic level because of their reproductive capacity, while men were in charge of hunting, ploughing and other physical tasks from the external field thanks to their physical strength (Medina et al., 2014; Saldívar et al., 2015). During the Industrialization (1750-1870), the external field was understood to be indispensable for survival. This gave masculinity a higher status compared to women (Wharton, 2012: 99). Thus, the role of women in society was underrated (Ribas, 2004: 3). What started as a separation set up for coexistence became a fixed ideal that distinguished, prioritized and opposed human beings according to their gender (Sartelli, 2018: 200-201).

With the beginning of the Second World War (1939-1945), married women that belonged to a middle class became responsible for their household economy while their husbands fought on the frontline (Coronado, 2013). When the conflict ended in 1945, they stopped working outside their homes (Brioso, 2011: 341). Sometime later, in the fifties, American women managed to have access to university education, although this opportunity was mostly offered as a possibility to be at the same cultural level as their future husbands (Del Valle, 2002: 99), because women had little to no room in the world of work and so in the end, they got married and devoted themselves to domestic work (Jódar, 2013).

In the sixties, Social Sciences analyse the gender-specific division of labour and validate that this is the cause of patriarchal domination in western societies (Brioso, 2011: 343). In turn, the women who were part of the new generations and who were more qualified both academically and professionally for the outside world, demanded opportunities in different fields and professional sectors (Ramos, 2003: 268). These advances were progressively achieved between the seventies and the eighties. They entry of women into the labour market made their husbands take part both in the household chores and in childcare. These responsibilities were added to the traditional role of men as main economic providers of the household, another responsibility that was shared between men and women (Cánovas, 2017: 6). 


\section{State of the art}

The lack of equality in male and female representation, assigning a lower scale to women when they are compared to men, is still presented in today's audiovisual content for all audiences, although it is an issue that began to be investigated in the 80s (Iadevito, 2014: 226). Nowadays, animation is a very powerful tool and children learn both the masculine and feminine ideals that predominate at a particular moment in history through their favorite characters (Pietraszkiewicz, 2017). Those stories help to perpetuate, eliminate or modify behavior patterns according to the gender assigned to the different characters and to what they do within the narrative (Bustillo, 2013: 6). Currently, "(...) preocupa sobre todo la violencia mediática que recae tanto en la representación de mujeres y hombres, en el tratamiento que se les concede a los personajes masculinos y femeninos, así como el efecto que causa sobre las y los espectadores"1 (Sánchez-Labella, 2915: 9).

For more than seventy years (1937-2009), Disney did not depict work as a subplot to develop relationships and/or as a tool to create conflicts amongst the different characters (Fonte, 2001: 131). It is true that different male characters such as the hunter from Snow White and the Seven Dwarfs (1937), the butler from The Aristocats (1970), the explorer John Smith from Pocahontas (1995), or the Beast's servants (Beauty and the Beast, 1991) had jobs and these jobs were important within the story. However, in these examples, their occupation is just another piece of information about the characters and there barely is any screen time where these characters are shown doing their job.

Disney used the traditional feminine roles in their feature films. They chose to keep the more traditional vision of femininity that still prevails in our modern age. Due to this, male perceptions dominated the world view that was used for film adaptations. Thus, in its stories, the studio adhered to the traditional role of women within marriage and the home (Davis, 2006: 102). In addition to this, the studio also made stories to be a "factor de transmisión cultural utilizado principalmente durante la socialización primaria que permite inculcar valores diversos" (Sartelli, 2018: 213).

In 2009, the Princess and the Frog was released, and Disney's first working princess emerged (Johnson, 2015). In this film, work has an influence on the main character's moods, on her decision-taking and even on her relationships with the rest of the characters (Aguado \& Martínez, 2015: 56).

\footnotetext{
${ }^{1}$ Translated by the authors: "The media violence that concerns both the representation of women and men, the treatment given to male and female characters as well as the effect it causes on the spectators is especially concerned."
} 
By then, Pixar had already been producing feature films for fourteen years. In particular, between 1995 and 2015, eleven out of the sixteen films that were released (66\%) address the topic of work and the division of labour as an essential matter in the subplots of their scripts. Since their second release, $A$ Bug's Life (1998), work is part of both the individual and the collective identity of the characters. Jonathan Decker's research emphasizes that Pixar is an example to follow. In Decker's analysis all the characters appeared between 1995 and 2010 have access to the same conditions and opportunities in the labour market, regardless of their gender (Decker, 2010: 86 \& 87). Following Decker's statement, an analysis is carried out to try to determine whether that statement is true for the two decades that have been analysed.

\section{Methodology}

This research aims to describe and analyze the male and female characters in Hollywood's commercial animation cinema through the viewing of the sixteen films made by Pixar Animation Studio since 1995, the year in which they began production, until 2015.This current research starts by quantifying the number of characters that are shown working in the sixteen films released by Pixar between 1995 and 2015. Once these results were obtained, it has been determined which are the occupations for men and for women that have been depicted in the representative sample quantifying again. Finally, we have added a table in which the name of the character, his/her gender, his/her profession and his/her narrative archetype are organized in order to define how Pixar presents professions in male heros and/or male/female secondary characters.

Through the quantitative and qualitative analysis of the characters will allow us to detect and define the patterns of the masculine and feminine types created by Pixar and their evolution throughout the study time. Similarly, a comparison can be made between these and those that appeared in the Disney studio films. Through the study of differences and similarities in issues such as social representation, the physical aspect, the values they hold or gender relations, the aim is to determine to what extent society has changed and what is the image that is currently projected from the animation movies.

\section{Results}

\subsection{Quantity results}

In $60 \%$ of Pixar's stories, characters seek the same objective: to have professional success. In Pixar, this accomplishment is linked to maintaining their jobs, to having social recognition, or to both. In relation to the 
quantification of male and female workers, we can appreciate a big difference as it is represented in the following graph:

\section{Graph 1. Quantification of male and female characters in the representative sample (1995-2015)}

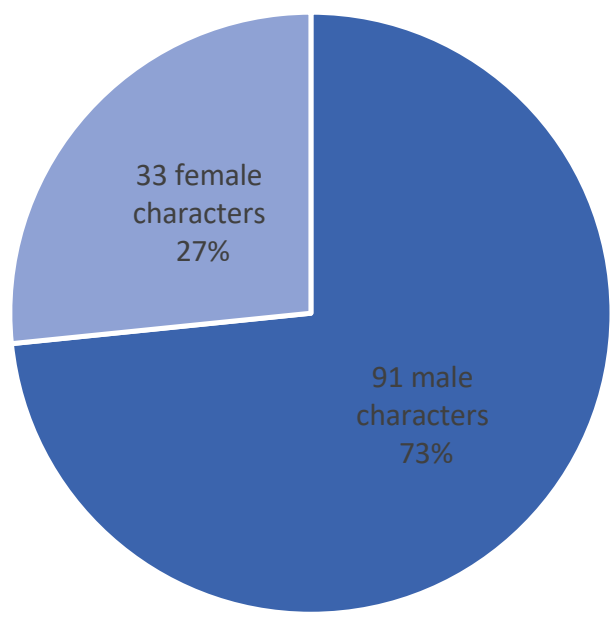

- 1 - 2

Source: own elaboration

After reviewing the films that were analyzed (Table 1 in Anex), it can be said that Cars (John Lasseter, 2006) and Ratatouille (Brad Bird, 2007) are the two films were there are more working male characters. On the other hand, $A$ Bug's Life, Cars and Brave (Mark Andrews and Brenda Chapman, 2012) are the films where we can find more working female characters: four in each of them. And Monsters University, (Dan Scanlon, 2013) despite the fact that it is a film with many male characters, it is the most equitable film out of the sixteen when it comes to work-related issues.

In fact, in 56.25\% of Pixar's films, the rupture of the everyday routine which the characters undergo is due to work-related issues. And in $43.75 \%$ of the cases, the beginning of this adventure that the main male characters are responsible for starts with their jobs. Only in two films there are female characters whose plots start with their jobs. This entails $12.5 \%$ of the feature films. One of them is Wall-E (Andrew Stanton, 2008), where EVE is in charge of searching for life on Earth. Her task marks the beginning of the adventure. 
It is worth stressing that the main objective that the characters from $60 \%$ of the films released by Pixar have, is related to labour issues. Moreover, in $56.25 \%$ of Pixar films, the break in the balance suffered by the characters in the story is due to a labour issue. And in $43.75 \%$ of the cases, the male protagonists are responsible for the start of this adventure in order to advance in their job and improve their status.

The crisis suffered by the company Monsters Inc. (Pete Docter, 2001) in the film affects Sully beyond his vocation as scary. Unwittingly, Sullivan is involved in a whole web of corruption and deception. In particular, Waternoose himself, the owner of the company, has an agreement with Sully's rival, Randall, so as to introduce human children in the factory for the purpose of increasing the energy levels, but also to recover his power and thus to supply all the city. All Monstropolis believe that children are toxic. The triggering incident that begins the story is when Sully discovers a small human girl who is two or three years old in the factory.

Mike's dream, at Monsters University, is to get to the best college of scarers. But although he studies and works very hard to achieve his dream, he does not have enough faculties. Thus, the green monster finds that he can be expelled from the university if he does not pass the exam. This is how Mike sees his dream falter and with it, his future work.

Laziness in Bob's work and his subsequent dismissal are the trigger for The Incredibles (Brad Bird, 2004). This situation coincides with the proposal of a new job position, adjusted to his profession of superhero. He does not hesitate to accept the successive missions proposed by Mirage, who is, in reality, the villain Syndrome's secretary and partner. In this way he begins his first internal change: with the new job, Bob is happier, he integrates better in his family, and both his adventure and his arc of transformation begin.

The missions for which Eva and Wall-E are programmed are, precisely, their respective jobs. The trigger to start the adventure in Wall-E arises when Wall-E decides to leave his job and his planet to take care of Eva, who has been picked up by a ship after entering a state of hibernation. This fact is relevant from the narrative point of view: the hero leaves his habitat and moves to his beloved leaving all his world behind. The beginning of the adventure coincides with what it was the 'happy ending' of Disney films starred by princesses. But, in this case, it is the male character who leaves everything to start a new life with his beloved Eva.

The breaking of the balance in the work environment also occurs in Cars, Lightning McQueen is used to competing and he feels he is the best on the track. McQueen cannot win the Piston Cup in the first race and travels to a new 
destination to get it. On the way he gets lost and does not reach the new competition. During his time in Radiator Springs, he discovers and learns values such as respect and friendship and to enjoy small moments. When he returns to work, McQueen has a new personality, with new values and real friendships.

In Cars 2 and Ratatouille the protagonists are involved in a work-related lie: Mate, as a spy and Lingüini, as a cook. Lingüini maintains the wrong idea that Gusteau's workers have made of him during a half of the film, while Mate barely realizes that he is working for some spies and that his contribution is very valuable. Both mistakes lead to the development of professions for which they do not seem to have the necessary skills. However, both Lingüini and Mate begin a journey in which they discover that they can be very happy exploiting their abilities and using themselves.

Only in two films there are female Pixar characters whose plot begins with work. This means $12.5 \%$ of the films. One of them is Wall-E, where Eva is responsible for looking for life on the planet Earth. Her mission is the trigger for the adventure to begin.

Atta's future job in A Bug's Life is the trigger to evolve and this leads to an adventure. Atta has to manage the ant colony, still with the help of her mother. Atta feels stressed and does not know how to face her new position. As soon as she starts exercising, even though all the ants are perfectly organized, Flik throws the food collected for months for the grasshoppers into the river. This is the beginning of an adventure for her to collect food again, which implies a greater organization and supervision of the members of the colony that this demands.

In $18.75 \%$ of the films, the responsibility in the work and narrative objective of their male partners directly affects female characters such as Helen, Colette and Riley. Helen abandons her housework and motherhood, her profession until she decides to go in search of Bob. Colette's adventure begins when she meets Lingüini. She is already a professional and Chef Skinner asks her to show him how Gusteau's kitchen works. After putting her trust in Lingüini, Colette loses her to discover that she has lied to him and decides to leave but realizes that Chef Gusteau's dream has come true: anyone can cook.

In Inside Out, Riley's father accepts a new position in San Francisco, and that's why the whole family move to the new city. His father's new job is the trigger that breaks the balance of the eleven-year-old girl. She is happy in her school, in her hockey team, with her friends and playing with her parents. However, in her new home her parents do not have so much time to spend with her, she does not have friends, she is not selected by another hockey team and she does not adapt to the new school. 
In $46.6 \%$ of the films, work is an element that provokes the arc of transformation of, at least, one of the characters. For example, the internal evolution of Helen in The Incredibles means that from the middle of the film until the end she takes care of her family, of combating evil and of supervising her image.

And with work there is also the fear of not measuring up, of doing it badly, although this fear is expressed unequally in male and female characters. Atta, Shiftwell and Helen have at some point a feeling that is not seen in the performance of the professions of male characters, except in Lingüini and this is because the boy is lying about his capabilities. $18.75 \%$ of the films have female characters who suffer crisis in their jobs that are due to the lack of security in themselves to show their ability as professionals and solve the contingencies that arise. On the other hand, male characters do not suffer professional crisis in the same way as female characters, they are confident in the performance of their tasks and know their abilities, as well as how to use them to achieve professional success.

Graph 2. Labour sectors. Pixar's male characters (1995-2015)

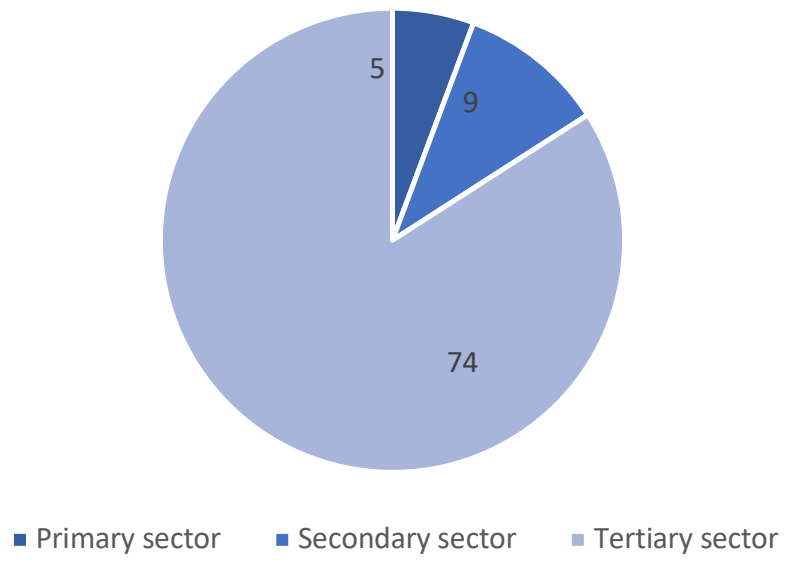

Source: own elaboration

The vast majority of working male characters ( 74 out of 91 characters) are dedicated to professions included in the tertiary sector (services), but there are also 9 characters whose work activity belongs to the secondary (industrial) sector and 5 male workers in the primary sector (agriculture). 
Graph 3. Labour sectors. Pixar's female characters (1995-2015)

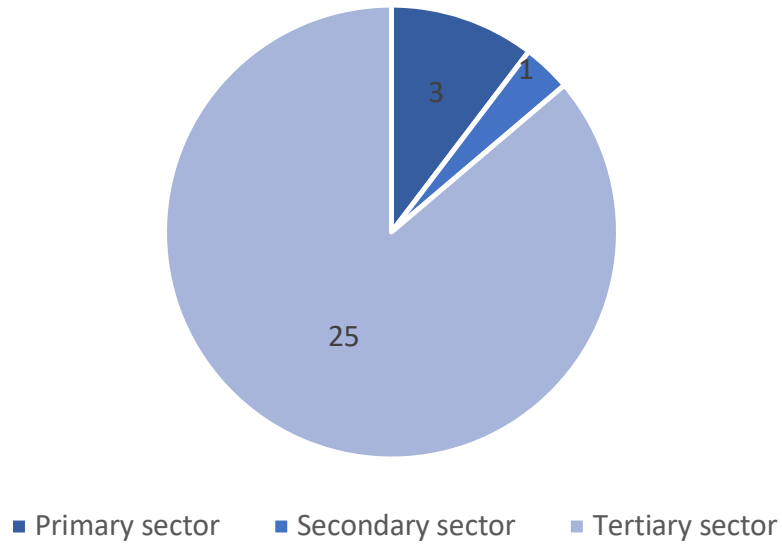

Source: own elaboration

In $33.3 \%$ of the Pixar filmography, female characters appear in jobs that, before the 80s, were conceived as typical of the male gender. Out of 125 worker characters, only 29 are women: almost all (25) work in the tertiary sector.

The vast majority of working male characters (74 of 91 characters) are dedicated to professions included in the tertiary sector (services), but there are also 3 characters whose work activity is included in the secondary (industrial) sector and 5 male workers, in the primary sector (agriculture).

In any case, the social changes of the last fifty years have allowed women to enter the world of work outside the home. And this moved to the cinema from the $90 \mathrm{~s}$. Although $81.25 \%$ of female characters occupy positions with little decision-making capacity or in traditionally feminine areas (education, care for others, sewing, cleaning, cooking), Pixar has also created female characters that break the work box. Female characters begin to occupy high positions: $18.75 \%$ of the films include female characters who lead a company or even a community.

With all this information we can summarise that, quantitatively, Pixar underrepresent female characters when it comes to the employment sphere. But, beyond this quantification, we will continue our analysis by describing what the jobs are for each gender to find that there also is underrepresentation in the job positions. In order to do this, and before describing the professions of each character (and their narrative archetype in the story) we have included a table in Anex (Table 4. Characters, gender and professions in the representative sample. Compilation). 


\subsection{Quality results}

\subsubsection{Male jobs in Pixar's films}

In Pixar, the division of labour outside the home has been influenced by the Western gender division (Medialdea, 2016: 90). Pixar represent the traditional system of task division which has always been associated to the family as an institution, and its influence on the gender-specific division of labour can be seen in The Incredibles and in Brave (Martínez, 2017: 354). Bob (The Incredibles, 2005) and Fergus (Brave, 2012) are the husbands within a traditional family which starts by getting married to their wives and then having children, in that order (Gálvez, 2009: 11). The two of them represent the 'breadwinner' (Wharton, 2012: 104). Their wives, Helen and Elinor, respectively, do not work outside their homes. Helen does leave to rescue her husband as a superheroine, but she does so because of her duty as a housewife that cares for her family, and as someone that wants to keep all of them together, not as part of her professional development. As for Elinor, she is the queen and she is to raise her daughter Merida so that she is ready to inherit her role. Elinor always does so inside the castle as part of her maternity. It is also worth mentioning here that for Bob, his job is an essential aspect of his own individual/personal development. Bob's own apathy when it comes to his job and his subsequent dismissal are part of the trigger in The Incredibles. This situation happens at the same time as Bob gets an offer for a new job position which matches his job as a superhero. He does not hesitate to accept the following missions that are proposed by Mirage, who in reality is the villain Syndrome's secretary and partner. His first internal changes start like this: with his new job, Bob is happier, his relationship with his family improves, and both his adventure and his transformation start.

In Pixar, the jobs that the male characters have are quite varied: chef, sheriff, space ranger, athlete, chief detective, firefighter, soldier, entrepreneur, administration chief or judge, amongst others². Sulley and Mike from Monsters, Inc. work in the Monsters, Inc. Company scaring children. Both of them are happy and they are successful thanks to their hard work and their daily efforts. This situation can also be seen at Gusteau's restaurant in Ratatouille, where all the workers are male except for Colette. Haute cuisine has always been considered a male domain and Ratatouille still represents this work environment in this way (Del Valle, 2002: 96).

2 As it happens in Ratatouille, Cars or Wall-E. 
Within Pixar's masculinity, there is a complex hierarchical system where preference is given to those males that fulfil the established social norm: the workers that are successful are those who are tolerant, modest, who know to work in teams and whose sense of team spirit has been developed, giving preference to the labour necessities that others have, even over their own. This can be seen in Remy, from Ratatouille, and this is what McQueen, from Cars, and Bob, from The Incredibles, learn.

Teaching and cleaning are two jobs that are barely relevant to male characters within Pixar, but they do appear respectively in Finding Nemo and Toy Story 3. Cleaning has been a task traditionally assigned to women as part of the household chores, and something that they could continue doing outside it (Goñi, 2002). The figure of the teacher has always been a clear reference to authority and power in the western society (Del Valle, 2002: 117). Showing a male preschool teacher in one of their first films reinforces Pixar's search of progress towards gender equality. Different sectors such as education and the health service have always been associated to the female gender (Medialdea, 2016: 93).

\subsubsection{The inclusion of Pixar's female characters in the world of work}

Social changes like divorce or women's access to university allowed women to enter the labour market outside the home, regardless of their marital status (Gálvez, 2009: 15). These changes were reflected in animation films during the nineties ${ }^{3} .81 .25 \%$ of the Pixar's female characters analysed hold positions with little decision-making capacities, or in areas that have always been traditionally associated with women: education, caring for others, dressmaking, cleaning, or cooking. Pixar have also created female characters that break the stereotypes related to the inability to climb the professional ladder, but this does not happen very often.

In $33.3 \%$ of Pixar's films, there are female characters that hold job positions that, before the eighties, were traditionally associated with men. Only three female characters hold the position with the highest responsibility within the companies where they work, thus copying the western social model that prevailed at the moment of filmings (Gómez, 2018: 178). These characters are Roz (Monsters, Inc., 2001), dean Hardscrabble (Monsters

\footnotetext{
${ }^{3}$ Pocahontas (1995) is one of the Disney animated films related to this because the main character decides not to get married and not to give up her responsibilities as a leader instead of travelling to London with Smith. Before Pocahontas, Belle in The Beauty and the Beast (1991) doesn't get married to the handsome Gaston, Belle decides who is going to be her partner.
} 
University, 2013) and Atta from A Bug's Life (1998). According to Eisenhauer, we have been socially educated to understand that both power and authority are male characteristics, while femininity is characterised by the lack of power (Eisenhauer, 2017: 14-15). Focusing on Roz and Hardscrabble, both have a masculine aspect, an idea that makes reference to independent, strong, active, determined and self-confident women (Del Valle, 2002: 167-168). Roz (Monsters, Inc., 2001) is an undercover agent. Dean Hardscrabble, in Monsters University, faces the responsibility of leading an entire university campus after being promoted since she started as a student. In both films we can see two female characters that are presented as modern women, that " (...) se han atrevido a transgredir los roles y estereotipos de género prescritos tradicionalmente" 4 (Ramos, 2003: 268).

Roz and Hardscrabble have something in common: their professional activity is linked to a personality where they stand firm in their convictions and strict in their way of acting. This is the idea of leadership in the real world (Martínez Ayuso, 2015: 50). Montesinos (2002: 49) considers that these are two characteristics that appear in women when they have to lead because it was job position that in previous decades was traditionally male, and they take that as reference.

Roz and Hardscrabble establish cold and distant relationships with the rest of the characters. This can be compared with the image of the woman that abuses her power and which has been reflected in Disney's witches and female villains until 2016 (Streiff \& Dundes, 2017: 9). In fact, throughout the film, we do not know anything about the private lives of these two characters. We only know them through their job interests. The lack of social relationships, or their non-appearance (in particular, family and love relationships) may have to do with this full dedication to their jobs, because this is how it happens in the real world (Medialdea, 2016: 96). These characteristics have nothing to do with the traditional view of femininity in which women were understood to be sensitive and close to others, which facilitated their relationships with others (Lamo de Espinosa, 2000: 82). Roz and dean Hardscrabble are proof that, nowadays, any woman can lead a university campus or be part of the judicial field, which has traditionally been led by men. However, the strict way in which they do their jobs and teach the characters is rejected by the audience, at least at first. Both Roz and dean Hardscrabble represent the idea of femininity and leadership that was proposed by Colón, Plaza and Vargas (2013: 68): “(...) las mujeres que

\footnotetext{
${ }^{4}$ Translated by authors: (Pixar) "has dared to transgress traditionally and prescribed gender roles and stereotypes."
} 
transgreden el mandato social se estigmatizan todavía como poco respetables y confiables, mala mujer y madre" 5 . At the end of the films, it is confirmed that the strict attitude the two of them had, was based on everybody's protection and well-being when fulfilling the established rules, and that shows a more positive image.

Atta in A Bug's Life (1998) inherits the leader position in the ant colony from her mother, so she rules as queen. It is important to emphasise that she has this power because she inherits it, not because she has earned it or because she has proven that she can be the colony leader. In the real world, family businesses are usually inherited by men (Gatrell, 2008: 12). This is an important change: Princess Atta actively participates in the public life and she progresses socially without the need of a husband or another male to attain her position. Let us remember that Disney did not include a leader princess exercising her responsibilities without a spouse until Elsa in Frozen (2013) (Johnson, 2015: 24). Del Valle believes that female leadership is different from that of males. Regarding the former, she states that women are more concerned about doing things right, while men tend to be more individualistic (Del Valle, 2002: 195-200). It is also worth mentioning that Atta's future job is the trigger needed to evolve and this results in an adventure. Atta has to manage the ant colony, although she still has her mother's help.

Despite all that has been mentioned before, in Pixar there is a predominance of women whose jobs indicate there are inequalities between men and women. In this regard, Pixar's films strengthen Haywood's idea that says that the distribution of job positions has not changed (Haywood, 2003: $25)$. In this sense, Pixar adjust to the pace that the society which the films are directed to, have. The jobs that women have held, even after their access to the university sector and the world of work, are linked to their service to others: health, education, household chores, restaurants and hotels (González, 2004: 6-9).

Colette, in Ratatouille, and Edna from The Incredibles, have a lot to do with this. The former is the only female cook at Gusteau's and she tells Lingüini the efforts she has made in order to work there. Edna is a dressmaker, and sewing was linked to household chores until the middle of the $20^{\text {th }}$ century, and therefore, to women.

\footnotetext{
${ }^{5}$ Translated by the authors: "women who transgress the social mandate are still stigmatized as little respectable and unreliable, bad woman and mother."
} 
In Pixar there are also female secretaries, waitresses, female teachers, flight attendants or receptionists. Pixar represent these occupations through female characters in $20 \%$ of the films. Out of all of them, only the job as a teacher is portrayed by a male character. It is exactly within that care for others where the teacher's job lies. It is thought that the job as primary teachers is mainly carried out by women because "(...) la sociedad supone que las mujeres son cooperativas, comprensivas, amables y apoyan a los demás"6 (Ramos, 2003: 273). Every single teacher we see at Sunnyside (the Toy Story 3 nursery) are women, just like Mike Wazowski's teacher in primary school, which can be seen at the beginning of Monsters University, is also a woman. The performance of this work with little children is connected to the traditional idea that states that women are equipped with an emotional development that makes it easier for them to look after and meet the needs of babies and children until primary school much better than any man would (Pascual, 2014). There are other female characters in professional fields that have traditionally been associated with women, such as Barbie, in Toy Story 2, and Gypsy, from A Bug's Life. Both of them are flight attendants and they share the importance that their physical aspects have in order to do their jobs and their ability to serve others.

\section{Conclusions}

To start with, it is important to take into account that this research has the limitations of an experimental design based on a limited number of observations, but, we have to bear in mind that the results are relevant to have a much better knowledge of how male and female representations are built in animation films. As it is known, we cannot forget that "el hecho de que los dibujos animados contengan gran cantidad de referencias de la vida real hace que los consumidores a veces entiendan las historias y las acciones como verosímiles"7 (Sánchez-Labella, 2015: 10).

While Disney proposed the first working male character in Snow White and the Seven Dwarfs (1937) and the first working princess in 2009 with Tiana and the frog, Pixar already present work as a main field. In it, male and female characters develop their capacities and success since its second premiere: $A$ Bug's Life (1998). Therefore, in Pixar, the male and female role at work is, without a doubt, the relationship that has developed the most in Pixar if we compare it with Disney.

\footnotetext{
${ }^{6}$ Translated by the authors: "society assumes that women are cooperative, understanding, kind and supportive of others"

${ }^{7}$ Translated by the authors: "The fact that cartoons contain a lot of real-life references makes consumers sometimes understand stories and actions as plausible."
} 
In Pixar's labour world, like in the western real world, power is embodied by men (Meza, 2018: 11). In this way, Pixar follow the idea of presenting working female characters. However, only a minority of them hold high positions. Following the system that still remains in the current western world, jobs are still highly sexualized (Hidalgo Marí, 2017: 310-311), as films analyses showed us. This also happens in the real world, in particular in positions such as receptionists, secretaries or waitresses (Gatrell, 2008: 42).

After this analysis, we can also prove that helping, services and caring for others are qualities which are still associated with the female identity (Jenaro, 2014: 51). Regarding male characters, Pixar still present male success as part of having a good job which makes them grow. Working on developing masculinity and femininity in equality, Pixar have only needed twenty years to increase and improve their gender representation.

The female characters of Pixar are professionals able to work in any field and demonstrate with their skills that they are 'competent professionals' in their area, although the services sector is still the one that covers the vast majority of female characters in the 20 years analysed: they work there $81.25 \%$ of the times. Revising this information and comparing with the western world nowadays:

The EU's aim is to reach a $75 \%$ employment rate for men and women by 2025. In 2017, female employment continued to increase slowly but steadily, similarly to that of men, and reached $66.6 \%$ in the third quarter of 2017. Despite this progress, women are still a long way off achieving full economic independence. In comparison to men, women still tend to be employed less, are employed in lower-paid sectors, work on average 6 hours longer per week than men in total (paid and unpaid) but have fewer paid hours, take more career breaks and face fewer and slower promotions (European Union, 2018: 9).

In fact, Pixar's female characters suffer a vertical segregation in access to jobs with power. Therefore, despite the evolution shown by the characters under the icon 'superwoman', they continue to work, mostly, in positions traditionally assigned to the female gender, as also happens with male characters, where there is only one teacher, one waiter and one cleaner out of the total 16 films:

No obstante, la igualdad no se ha conseguido, pese a que sea indiscutible que se ha producido un cambio en los modelos de feminidad y masculinidad actuales respecto al siglo XX. Los datos económicos y laborales más 
actuales muestran que los antiguos roles de género todavía no han sido desterrados del mundo del trabajo (... $)^{8}$ (Martínez, 2017: 135).

Pixar's male characters live devoted to their work and that is the reason for the beginning of the adventure (or it is related to it) in just over half of the films (56.25\%). Therefore, this masculine behavior (valuing work above or at the same level as other relationships) is presented as something natural.

Mass media are a very powerful tool to present different options regarding masculinity and femininity that can guide us towards equality and a stage of normalization (Johannah, 2018). In addition to this, it is essential to point out how necessary it is to design characters that attract children but that encourage them as well, in order to choose their future work life because of their abilities and interests and not because of their gender. In addition to this, it is needed to point out how necessary is to design characters that attract children but that encourage them as well, in order to choose their future labour life because of their abilities and interests and not because of their gender.

\section{Bibliography}

AGUADO, D. y MARTíNEZ, P. (2015). ¿Se ha vuelto Disney feminista? Un nuevo modelo de princesas empoderadas. Área Abierta, 15 (2), 49-61. Consultado el 11 de enero de 2019:

https://www.academia.edu/13694941/_Se_ha_vuelto_Disney_femin ista_Un_nuevo_modelo_de_princesas_empoderadas?auto=download

UNIÓN EUROPEA (2018). 2018 Report on equality between women and men in the UE. Luxemburgo: OIB.

MARTíneZ, M. (2017). Desmontando clichés o la evolución de los modelos de feminidad y masculinidad en los escenarios. En García-Ferrón, E. y Ros-Berenguer C. (coords.), Dramaturgia femenina actual. De 1986 a 2016. Feminismo/s (30), $129-145$.

BoGINO, M. y FERNÁNDEZ-RESINES P. (2017). Relecturas de género: concepto normativo y categoría crítica. La ventana (45), 158-185.

Brioso, A.B. (2011). Perspectivas de género como pieza fundamental en trabajo social. Consultado el 15 de abril de 2018:

https://docplayer.es/5268781-Perspectivas-de-genero-como-piezafundamental-en-trabajo-social.html

\footnotetext{
${ }^{8}$ Translated by the authors: "However, equality has not been achieved, despite the indisputable fact that there has been a change in the current models of femininity and masculinity with respect to the 20th century. The most current economic and labor data shows that the old gender roles have not yet been banished from the world of work."
} 
Bustillo, M. (2013). Conocimientos y valores en el cine. Una propuesta para 6음 de primaria. (TFG). Facultad de Educación de la UNIR. La Rioja. Consultado el 16 de enero de 2019:

https://reunir.unir.net/handle/123456789/1865

CÁnOVAS MARMO, C. (2017). Las mujeres, el laberinto cultural y la asunción del pensamiento crítico. Management Review, 2 (2). Consultado el 10 de diciembre 2018:

https: / / dialnet.unirioja.es/servlet/articulo?codigo $=\mathbf{6 0 5 4 2 2 1}$

Colon, A., PlazA, A., \& VARGAS, L. (2013). Construcción socio-cultural de la feminidad. Informes Psicológcios 13 (1), 65-90.

CoRonAdo, C. (2013). Mujeres en guerra: la imagen de la mujer italiana en los noticiarios Luce durante la Segunda Guerra Mundial (1940-1945). Revista de Estudios de Género. La ventana, 177-208. Consultado el 23 de octubre del 2018: http://www.scielo.org.mx/pdf/laven/v4n37/v4n37a8.pdf

DAVIS, A.M. (2006). Good Girls and Wicked Witches. Women in Disney's Feature Animation. Bloomington, Estados Unidos: Indiana University Press.

DECKER, J., (2010). The Portrayal of Gender in the Feature-Length Films of Pixar Animation Studios: A Content Analysis. (Thesis). Auburn University, Alabama. Consultado el 12 de febrero de 2014: https://etd.auburn.edu/handle/10415/2100

DEL VALLE, T.A. (2002). Modelos emergentes en los sistemas y las relaciones de género. Madrid, España: Narcea S.A.

EISENHAUER, K. (2017). Gendered compliment behavior in Disney and Pixar: A Quantitative Analysis. Consultado el 22 de diciembre de 2018: www.kareneisenhauer.org/wp.../Eisenhauer-Capstone-Excerpt.pdf

FonTE, J. (2001). Walt Disney. El universo animado de los largometrajes 19702001. Madrid: T \& B Editores,

GÁLVEZ, R. (2009). Comunicación, género y prevención de violencia. Manual para comunicadores y comunicadoras. Fondo de Población de Naciones Unidas (UNFRA). Consultado el 25 de enero de 2015:

americalatinagenera.org/newsite/images/sistematizacion_exp_dipl omado_honduras.pdf

GATRELL, C.S. (2008). Gender and Diversity in Management. A Concise Introduction. Londres, Inglaterra: SAGE.

GómEZ, M. (2018). Jornadas nacionales: el acceso de las mujeres al deporte profesional: el caso del fútbol. Seminario Mujer y Deporte. Madrid: Femeris. doi.org/10.20318/femeris.2018.4325

GONZÁLEZ, S.M. (2004). Igualdad de oportunidades entre mujeres y hombres en el mercado laboral. Encuentro de empresarias de la Macaronesia, Universidad Las Palmas de Gran Canaria, 1-25.

GoÑI, C. (2008). Lo femenino. Género y diferencia. Pamplona: EUNSA. 
HaYwood, C.Y. (2003). Men and Masculinities: Theory, research and social practice. Buckingham, Inglaterra: Open University Press.

HIDALGO, T. (2017). De la maternidad al empoderamiento: una panorámica sobre la representación de la mujer en la ficción española. Prisma Social (2), 291-314.

IADEVITO, P. (2014). Teorías de género y cine. Un aporte a los estudios de la representación. Universitas Humanística 78, 211-237

doi. org/10.11144/Javeriana.UH78.tgcu.

JENARO, C.F. (2014). Actitudes hacia la diversidad: el papel del género y de la formación. Cuestiones de género: de la igualdad y la diferencia (9), 20-62.

JóDAR, C. (2013). Arquitectura y vida americana de los '50. Recuperado de Amanece Metrópolis: Consultado el 23 de octubre del 2018: http://amanecemetropolis.net/the-good-wife-arquitectura-y-vidaamericana-de-los-50/

JOHANNAH, L. (2018). Women's Voice in humanitarian media. No surprises. Consultado el 19 de diciembre de 2018:

https://humanitarianadvisorygroup.org/wp-content/uploads/ 2018/03/HAG-Womens-Voice-in-Humanitarian-Media.pdf

JoHnSON, R.M., (2015). The Evolution of Disney Princesses and their Effect on Body Image, Gender Roles, and the Portrayal of Love. Educational Specialist. 6. https://commons.lib.jmu.edu/edspec201019/6

LAMO DE ESPINOSA, E. (2000). La feminización de la reproducción: ambivalencia, desasosiego y paradojas. En Durán, M. Á. Nuevos objetivos de igualdad en el siglo XXI. Las relaciones entre mujeres y hombres (75-98). Madrid, España: Publicaciones DGM.

MARTínEZ, V. (2015). Causas del techo de cristal: un estudio aplicado a las empresas del IBEX35. (Tesis) Facultad de Ciencias Económicas y Empresariales. UNED.

MARTíNEZ, J.A. (2017). Estereotipo, prejuicio y discriminación hacia las mujeres. Cuestiones de género: de la igualdad y la diferencia (12), 347-364.

MEDIALDEA, B. (2016). Discriminación laboral y trabajo de cuidados: el derecho de las mujeres jóvenes a no decidir. ATLÁNTICAS - Revista Internacional de Estudios Feministas 1 (1), 90-107. doi.org/10.17979/arief.2016.1.1.1792

MEDINA, P., FIGUERAS, M. y GóMEZ, L. (2014): El ideal de madre en el siglo XXI. La representación de la maternidad en las revistas de familia. Estudios sobre el Mensaje Periodístico 20, (1), 487-504. Madrid, Servicio de Publicaciones de la Universidad Complutense.

MEZA, C.A. (2018). Discriminación laboral por género: una mirada desde el efecto techo de cristal. Equidad y Desarrollo (32), 11-31. Consultado el 28 
de diciembre de 2018:

\section{https://ideas.repec.org/a/col/000452/016465.html}

MONTESINOS, R. (2002). Las rutas de la masculinidad. Ensayos sobre el cambio cultural y el mundo moderno. Barcelona, España: Biblioteca Iberoamericana de Pensamiento. Gedisa.

PASCUAL, G. (2014). La educación infantil, ¿un trabajo de mujeres? (TFG) Universidad de La Rioja. Consultado el 23 de octubre del 2018: https://biblioteca.unirioja.es/tfe_e/TFE000701.pdf

PIETRASZKIEWICZ, A. (2017). Masculinity Ideology and Subjective Well-Being in a Sample of Polish Men and Women. Polish Psychological Bulletin 48 (1), 79-86.

RAMOS, A.B. (2003). Mujeres directivas, espacio de poder y relaciones de género. Anuario de Psicología, 267-278.

RIBAS BONET, M.A. (2004). Desigualdades de género en el mercado laboral: un problema actual.

SAldívar, A., Díaz, R., Reyes, N. E., ARMEnTA, C., LÓPEZ, F., Moreno, M., Romero, A., HERNÁNDEZ, J., DomínGUEZ, M. (2015). Roles de Género y Diversidad: Validación de una Escala en Varios Contextos Culturales. Acta de Investigación Psicológica - Psychological Research Records. Consultado el 17 de octubre de 2081: http://www.redalyc.org/articulo.oa?id $=\mathbf{3 5 8 9 4 3 6 4 9 0 0 3}$

SÁnCHEZ-LABELLA, I. (2015) Veo Veo, qué ven. Uso y abuso de los dibujos animados. Pautas para un consumo responsable. Madrid, Inquietarte.

SANELEUTERIO, E. y LÓPEZ-GARCíA-TORRES, R. (2018). Algunos personajes Disney en la formación infantil y juvenil: otro reparto de roles entre sexos es posible. Cuestiones de género: de la igualdad y la diferencia (13), 209-224.

SARTELLI, S.L. (2018). Los roles de género en cuentos infantiles: perspectivas no tradicionales. Derecho y Ciencias Sociales (18), 199-218.

STREIFF, M. y DunDES, L. (2017). From Shapeshifter to Lava Monster: Gender Stereotypes in Disney's Moana. Social Science 6 (91). Consultado el 18 de diciembre de 2018: www.mdpi.com/journal/socsci

VEISSIÈRE, S.P.L. (2018). Toxic Masculinity in the age of \#MeToo: ritual, morality and gender archetypes across cultures, Society and Business Review.

WHARTON, A.S. (2012). The Sociology of Gender. An Introduction to Theory and Research. Oxford, Inglaterra: Wiley-Blackwell. 


\section{Anex}

Table 1. Quantification of characters in the representative sample. Compilation

\begin{tabular}{|l|r|r|r|}
\hline \multicolumn{1}{|c|}{ Film } & \multicolumn{1}{|c|}{$\begin{array}{c}\text { Total number } \\
\text { of male characters } \\
\text { (workers) }\end{array}$} & $\begin{array}{c}\text { Total number of } \\
\text { female characters } \\
\text { (workers) }\end{array}$ & $\begin{array}{c}\text { Total } \\
\text { number }\end{array}$ \\
\hline Toy Story (1995) & 3 & 0 & 3 \\
\hline A Bug's Life (1998) & 8 & 4 & 12 \\
\hline Toy Story 2 (1999) & 4 & 3 & 7 \\
\hline Monsters, Inc. (2001) & 6 & 2 & 8 \\
\hline Finding Nemo (2003) & 2 & 1 & 3 \\
\hline The Incredibles (2005) & 6 & 3 & 9 \\
\hline Cars (2006) & 15 & 4 & 19 \\
\hline Ratatouille (2007) & 12 & 1 & 13 \\
\hline Wall-E (2008) & 4 & 1 & 5 \\
\hline Up (2009) & 8 & 1 & 9 \\
\hline Toy Story 3 (2010) & 5 & 3 & 8 \\
\hline Cars 2 (2011) & 7 & 1 & 8 \\
\hline Brave (2012) & 4 & 4 & 8 \\
\hline Monsters University (2013) & 3 & 3 & 6 \\
\hline Inside Out (2015) & 1 & 0 & 1 \\
\hline The Good Dinosaur (2015) & 3 & 2 & 5 \\
\hline & 91 & 33 & 125 \\
\hline
\end{tabular}


\begin{tabular}{l|l} 
indexecomunicación | no 10(1), 2020 | Ordinario \\
\hline 118
\end{tabular}

Table 2. Labour sectors male characters. Compilation

\begin{tabular}{|c|c|c|c|}
\hline Film & $\begin{array}{l}\text { Primary sector } \\
\text { (agriculture) }\end{array}$ & $\begin{array}{l}\text { Secondary } \\
\text { sector } \\
\text { (industry) }\end{array}$ & $\begin{array}{l}\text { Tertiary sector } \\
\text { (services) }\end{array}$ \\
\hline Toy Story (1995) & & & 3 \\
\hline A Bug's Life (1998) & 1 & & 7 \\
\hline Toy Story 2 (1999) & 1 & & 3 \\
\hline Monsters, Inc. (2001) & & 6 & \\
\hline Finding Nemo (2003) & & & 2 \\
\hline The Incredibles (2005) & & & 6 \\
\hline Cars (2006) & & & 15 \\
\hline Ratatouille (2007) & & & 11 \\
\hline Wall-E (2008) & & 2 & 2 \\
\hline Up (2009) & & 1 & 8 \\
\hline Toy Story 3 (2010) & & & 4 \\
\hline Cars 2 (2011) & & & 7 \\
\hline Brave (2012) & & & 4 \\
\hline Monsters University (2013) & & & 1 \\
\hline Inside Out (2015) & & & 1 \\
\hline The Good Dinosaur (2015) & 3 & & \\
\hline
\end{tabular}

Table 3. Labor sectors female characters. Compilation

\begin{tabular}{|l|l|l|r|}
\hline \multicolumn{1}{|c|}{ Film } & $\begin{array}{c}\text { Primary sector } \\
\text { (agriculture) }\end{array}$ & $\begin{array}{c}\text { Secondary } \\
\text { sector } \\
\text { (industry) }\end{array}$ & $\begin{array}{c}\text { Tertiary sector } \\
\text { (services) }\end{array}$ \\
\hline Toy Story (1995) & & & 4 \\
\hline A Bug's Life (1998) & & & 1 \\
\hline Toy Story 2 (1999) & & & 1 \\
\hline Monsters, Inc. (2001) & & & 3 \\
\hline Finding Nemo (2003) & & & 4 \\
\hline The Incredibles (2005) & & & 1 \\
\hline Cars (2006) & & & 1 \\
\hline Ratatouille (2007) & & & 1 \\
\hline Wall-E (2008) & & & 4 \\
\hline Up (2009) & & & 2 \\
\hline Toy Story 3 (2010) & & & 1 \\
\hline Cars 2 (2011) & & & \\
\hline Brave (2012) & & & \\
\hline Monsters University (2013) & & & \\
\hline Inside Out (2015) & & & \\
\hline The Good Dinosaur (2015) & & & \\
\hline
\end{tabular}


Table 4. Characters, gender and professions in the representative sample. Compilation

\begin{tabular}{|c|c|c|c|c|}
\hline Film & $\begin{array}{l}\text { Character's } \\
\text { name }\end{array}$ & Gender & Profession & Archetype \\
\hline Toy Story & Woody & Male & Sheriff & Hero \\
\hline Toy Story & Buzz & Male & Astronaut & Hero \\
\hline Toy Story & Andy's mother & Female & Mother & Hero's mother \\
\hline Toy Story & $\begin{array}{l}\text { Pizza Planet's } \\
\text { delivery man }\end{array}$ & Male & $\begin{array}{l}\text { Pizza Planet's delivery } \\
\text { man }\end{array}$ & $\begin{array}{l}\text { Secondary } \\
\text { character }\end{array}$ \\
\hline A Bug's life & Atta & Female & Princess & Helper \\
\hline A Bug's life & Atta's mother & Female & Queen & Trickster \\
\hline A Bug's life & Flick & Male & Inventor and colector & Hero \\
\hline A Bug's life & P.T. & Male & Circus' owner & Trickster \\
\hline A Bug's life & Gipsy & Female & Event hostess & Trickster/Helper \\
\hline A Bug's life & Manny & Male & Fortune teller & Trickster/Helper \\
\hline A Bug's life & Francis & Male & Juggler & Trickster/Helper \\
\hline A Bug's life & Slim & Male & Juggler & Trickster/Helper \\
\hline A Bug's life & Rosie & Female & Tamer & Trickster/Helper \\
\hline A Bug's life & Dim & Male & Circus' beast & Trickster/Helper \\
\hline A Bug's life & Truck y Roll & Male & Comedians & Trickster/Helper \\
\hline Toy Story 2 & Woody & Male & Sheriff & Hero \\
\hline Toy Story 2 & Buzz & Male & Astronaut & Hero \\
\hline Toy Story 2 & Madre de Andy & Female & Mother & Hero's mother \\
\hline Toy Story 2 & Pete & Male & Foreman & Shadow \\
\hline Toy Story 2 & Jessy & Female & Cowgirl & Helper \\
\hline Toy Story 2 & Barbie & Female & Stewardess & Trickster \\
\hline Toy Story 2 & Al & Male & Toy Shop's owner & $\begin{array}{l}\text { Threshold } \\
\text { Guardian }\end{array}$ \\
\hline Monsters Inc. & Sully & Male & $\begin{array}{l}\text { Scarer (Factory's } \\
\text { operator) }\end{array}$ & Hero \\
\hline Monsters Inc. & Mike & Male & $\begin{array}{l}\text { Scarer's helper } \\
\text { (Factory's operator) }\end{array}$ & Hero/helper \\
\hline Monsters Inc. & Sr. Waternoose & Male & Factory's owner & Shadow \\
\hline Monsters Inc. & Randall & Male & Scarer (formerly) & $\begin{array}{l}\text { Threshold } \\
\text { guardian }\end{array}$ \\
\hline Monsters Inc. & Fungus & Male & \begin{tabular}{|l} 
Scarer's helper \\
(Factory's operator)
\end{tabular} & $\begin{array}{l}\text { Threshold } \\
\text { guardian's helper }\end{array}$ \\
\hline Monsters Inc. & Roz & Female & Secretary/CDA Boss & Shapeshifter \\
\hline Monsters Inc. & Celia & Female & Recepcionist & Trickster/Helper \\
\hline
\end{tabular}


indexecomunicación | no 10(1), 2020 | Ordinario

120

\begin{tabular}{|c|c|c|c|c|}
\hline Monsters Inc. & CDA workers & Male & CDA workers & $\begin{array}{l}\text { Secondary } \\
\text { character }\end{array}$ \\
\hline Finding Nemo & Marlin & Male & Father & Hero \\
\hline Finding Nemo & Nemo & Male & Student & Hero \\
\hline Finding Nemo & Mr. Ray & Male & Teacher & Trickster \\
\hline Finding Nemo & $\begin{array}{l}\text { Dr. Philippe } \\
\text { Sherman }\end{array}$ & Male & Dentist & $\begin{array}{l}\text { Threshold } \\
\text { guardian }\end{array}$ \\
\hline Finding Nemo & Barbara & Female & Recepcionist/secretary & $\begin{array}{l}\text { Secondary } \\
\text { character }\end{array}$ \\
\hline The Incredibles & Bob & Male & $\begin{array}{l}\text { Insurance seller, } \\
\text { superhero }\end{array}$ & Hero \\
\hline The Incredibles & Gilbert & Male & Bob's boss & $\begin{array}{l}\text { Threshold } \\
\text { guardian }\end{array}$ \\
\hline The Incredibles & Helen & Female & Housewife/superheroine & Helper \\
\hline The Incredibles & Edna & Female & $\begin{array}{l}\text { Dressmaker and } \\
\text { designer }\end{array}$ & Herald \\
\hline The Incredibles & Director colegio & Male & School principal & $\begin{array}{l}\text { Secondary } \\
\text { character }\end{array}$ \\
\hline The Incredibles & Dash's teacher & Male & Teacher & $\begin{array}{l}\text { Secondary } \\
\text { character }\end{array}$ \\
\hline The Incredibles & Syndrome & Male & Inventor & Shadow \\
\hline The Incredibles & Mirage & Male & Secretary & Shapeshifter \\
\hline The Incredibles & Frozone & Male & Superhero & Helper \\
\hline Cars & Rayo & Male & Race runner & Hero \\
\hline Cars & Mate & Male & Crane & Helper \\
\hline Cars & Chik Hicks & Male & Race runner & $\begin{array}{l}\text { Threshold } \\
\text { guardian }\end{array}$ \\
\hline Cars & El Rey & Male & Race runner & $\begin{array}{l}\text { Secondary } \\
\text { character }\end{array}$ \\
\hline Cars & Sally & Female & $\begin{array}{l}\text { Lawyer and hotel's } \\
\text { owner }\end{array}$ & Herald \\
\hline Cars & Flo & Female & Waitress & Trickster \\
\hline Cars & Ramón & Male & Workshop's owner & Trickster \\
\hline Cars & Doc Hudson & Male & $\begin{array}{l}\text { Jude and ex- race } \\
\text { runner }\end{array}$ & Mentor \\
\hline Cars & Mia & Female & Cheelader & Trickster \\
\hline Cars & Tia & Female & Cheelader & Trickster \\
\hline Cars & Luiggi & Male & Mechanic & Trickster \\
\hline Cars & Sheriff & Male & Sheriff & Trickster \\
\hline Cars & Mack & Male & Driver & Trickster \\
\hline
\end{tabular}




\begin{tabular}{|c|c|c|c|c|}
\hline Cars & Broadcaster (2) & Male & Broadcaster & $\begin{array}{l}\text { Secondary } \\
\text { character }\end{array}$ \\
\hline Cars & Manager & Male & Manager & $\begin{array}{l}\text { Secondary } \\
\text { character }\end{array}$ \\
\hline Cars & Guido & Male & Mechanic & Trickster \\
\hline Cars & Rojo & Male & Firefighter & Trickster \\
\hline Cars & Fillmore & Male & Militay & Trickster \\
\hline Ratatouille & Lingüini & Male & Cooker & Hero \\
\hline Ratatouille & Remy & Male & Cooker & Hero \\
\hline Ratatouille & Colette & Female & Cooker & Helper \\
\hline Ratatouille & Chef Skinner & Male & Chef & Shadow \\
\hline Ratatouille & Ego & Male & Culinary critic & $\begin{array}{l}\text { Threshold } \\
\text { guardian/Shapes. }\end{array}$ \\
\hline Ratatouille & Gusteau & Male & Chef & Herald \\
\hline Ratatouille & Inspector & Male & Sanitary Inspector & $\begin{array}{l}\text { Secondary } \\
\text { character }\end{array}$ \\
\hline Ratatouille & Ambrister & Male & Waiter & $\begin{array}{l}\text { Secondary } \\
\text { character }\end{array}$ \\
\hline Ratatouille & Horst & Male & Subchef & $\begin{array}{l}\text { Secondary } \\
\text { character }\end{array}$ \\
\hline Ratatouille & Larousse & Male & Cooker & $\begin{array}{l}\text { Secondary } \\
\text { character }\end{array}$ \\
\hline Ratatouille & Mustafa & Male & Waiter & $\begin{array}{l}\text { Secondary } \\
\text { character }\end{array}$ \\
\hline Ratatouille & Talon & Male & Lawyer & $\begin{array}{l}\text { Secondary } \\
\text { character }\end{array}$ \\
\hline Ratatouille & Django & Male & Unknown & $\begin{array}{l}\text { Threshold } \\
\text { guardian }\end{array}$ \\
\hline Wall-E & Wall-E & Male & Trash compactor & Hero \\
\hline Wall-E & EVA & Female & Explorer & Helper \\
\hline Wall-E & $\mathrm{M}-\mathrm{O}$ & Male & Maintenance operator & Ally \\
\hline Wall-E & Captain & Male & Ship Captain & Ally \\
\hline Wall-E & Auto & Male & Computer & Shadow \\
\hline$U p$ & Carl & Male & $\begin{array}{l}\text { Retired - exballon's } \\
\text { seller }\end{array}$ & Hero \\
\hline$U p$ & Russell & Male & Student and explorer & Hero \\
\hline$U p$ & Kevin & Male & Mother & Ally \\
\hline$U p$ & Charles Muntz & Male & Explorer & Shadow \\
\hline$U p$ & Ellie & Female & exballon's seller & Ally \\
\hline$U p$ & Dug & Male & Vigilant & Ally \\
\hline
\end{tabular}


indexecomunicación | no 10(1), 2020 | Ordinario

122

\begin{tabular}{|c|c|c|c|c|}
\hline Up & Beta y Gamma & Male & Vigilant & Shadow's helper \\
\hline$U p$ & Nurse A.J. & Male & Nurse A.J. & $\begin{array}{l}\text { Secondary } \\
\text { character }\end{array}$ \\
\hline Up & Nurse George & Male & Nurse George & $\begin{array}{l}\text { Secondary } \\
\text { character }\end{array}$ \\
\hline$U p$ & $\begin{array}{l}\text { Construction } \\
\text { manager }\end{array}$ & Male & Construction manager & $\begin{array}{l}\text { Secondary } \\
\text { character }\end{array}$ \\
\hline Toy Story 3 & Woody & Male & Sheriff & Hero \\
\hline Toy Story 3 & Buzz & Male & Astronaut & Hero \\
\hline Toy Story 3 & Andy's mother & Female & Mother & Herald \\
\hline Toy Story 3 & Jessy & Female & Cowgirl & Helper \\
\hline Toy Story 3 & Barbie & Female & Cowgirl & Ally/Trickster \\
\hline Toy Story 3 & Bonny's mother & Female & Teacher & $\begin{array}{l}\text { Secondary } \\
\text { character }\end{array}$ \\
\hline Toy Story 3 & $\begin{array}{l}\text { Maintenance } \\
\text { operator }\end{array}$ & Male & $\begin{array}{l}\text { Maintenance operator } \\
\text { and cleaner }\end{array}$ & $\begin{array}{l}\text { Secondary } \\
\text { character }\end{array}$ \\
\hline Toy Story 3 & Lotso & Male & Dictator & Shadow \\
\hline Cars 2 & Finn Mcmisile & Male & Spy & Mentor \\
\hline Cars 2 & Shiftwell & Female & Apprentice & Ally/helper \\
\hline Cars 2 & Mate & Male & Crane & Hero \\
\hline Cars 2 & Rayo & Male & Race runner & Herald \\
\hline Cars 2 & Miles Axelroad & Male & Bussinessman & Shadow \\
\hline Cars 2 & $\begin{array}{l}\text { Proffesor } \\
\text { Zündrap }\end{array}$ & Male & Gangster & $\begin{array}{l}\text { Threshold } \\
\text { guardian }\end{array}$ \\
\hline Cars 2 & Bernoulli & Male & Race runner & $\begin{array}{l}\text { Secondary } \\
\text { character }\end{array}$ \\
\hline Cars 2 & Sydelli & Male & Driver & $\begin{array}{l}\text { Secondary } \\
\text { character }\end{array}$ \\
\hline Brave & Fergus & Male & King & Hero \\
\hline Brave & Elinor & Female & Queen & Mentor/heroine \\
\hline Brave & Mérida & Female & Princess & Heroine \\
\hline Brave & Maudie & Female & Housekeeper & $\begin{array}{l}\text { Secondary } \\
\text { character }\end{array}$ \\
\hline Brave & Dingwall & Male & Lord & Trickster \\
\hline Brave & Macintosh & Male & Lord & Trickster \\
\hline Brave & Bruja & Female & Witch & Herald \\
\hline Brave & MacGuffin & Male & Lord & Trickster \\
\hline $\begin{array}{l}\text { Monsters } \\
\text { University }\end{array}$ & Mike & Male & Student & Hero \\
\hline
\end{tabular}




\begin{tabular}{|l|l|l|l|l|}
\hline $\begin{array}{l}\text { Monsters } \\
\text { University }\end{array}$ & Sulley & Male & Student & Hero \\
\hline $\begin{array}{l}\text { Monsters } \\
\text { University }\end{array}$ & $\begin{array}{l}\text { Abigail } \\
\text { Hardscrabble }\end{array}$ & Female & Doyenne & $\begin{array}{l}\text { Threshold } \\
\text { guardian } \\
\text { Shapshifter }\end{array}$ \\
\hline $\begin{array}{l}\text { Monsters } \\
\text { University }\end{array}$ & Professor Knight & Male & Professor & $\begin{array}{l}\text { Secondary } \\
\text { character }\end{array}$ \\
\hline $\begin{array}{l}\text { Monsters } \\
\text { University }\end{array}$ & Karen & Female & Teacher & $\begin{array}{l}\text { Secondary } \\
\text { character }\end{array}$ \\
\hline $\begin{array}{l}\text { Monsters } \\
\text { University }\end{array}$ & $\begin{array}{l}\text { Mrs Squibbles } \\
\text { (Mummy) }\end{array}$ & Female & Mother & $\begin{array}{l}\text { Secondary } \\
\text { character }\end{array}$ \\
\hline Inside Out & Bill Andersen & Male & Boss & Ally \\
\hline Inside Out & jill Andersen & Female & Unknown & Ally \\
\hline Inside Out & Riley Andersen & Female & Student & Heroine \\
\hline $\begin{array}{l}\text { The Good } \\
\text { Dinosaur }\end{array}$ & Poppa & Male & Farmer & Mentor \\
\hline $\begin{array}{l}\text { The Good } \\
\text { Dinosaur }\end{array}$ & Momma & Female & Farmer & $\begin{array}{l}\text { Secondary } \\
\text { character }\end{array}$ \\
\hline $\begin{array}{l}\text { The Good } \\
\text { Dinosaur }\end{array}$ & Buck & Male & Farmer & $\begin{array}{l}\text { Secondary } \\
\text { character }\end{array}$ \\
\hline $\begin{array}{l}\text { The Good } \\
\text { Dinosaur }\end{array}$ & Libby & Female & Farmer & $\begin{array}{l}\text { Secondary } \\
\text { character }\end{array}$ \\
\hline $\begin{array}{l}\text { The Good } \\
\text { Dinosaur }\end{array}$ & Arlo & Male & Farmer & Hero \\
\hline
\end{tabular}

